\title{
PLANT REFLECTED SPECTRA DEPENDING ON BIOLOGICAL CHARACTERISTICS AND GROWTH CONDITIONS
}

\author{
Amanda KARLOVSKA, Faculty of Agriculture, Latvia University of Agriculture, Liela street 2, Jelgava, LV-3001, Latvia, \\ amanda.karlovska@1lu.lv (corresponding author) \\ Inga GRĪNFELDE, Faculty of Rural Engineering, Latvia University of Agriculture, Akademijas street 19, Jelgava, LV-3001, \\ Latvia, inga.grinfelde@1lu.lv \\ Ina ALSIN̦A, Faculty of Agriculture, Latvia University of Agriculture, Liela street 2, Jelgava, LV-3001, Latvia, ina.alsina@1lu.lv \\ Gints PRIEDĪTIS, Forest Faculty, Latvia University of Agriculture, Akademijas street 11, Jelgava, LV-3001, Latvia, \\ gints.prieditis@1lu.lv \\ Daina ROZE, National Botanic Garden of Latvia, Miera street 1, Salaspils, LV-2169, Jelgava, Latvia, nbd@nbd.gov.lv
}

Sustainable and economically based forestry needs modern inventory and monitoring techniques. One of the most common technologies for identification of forest tree species and monitoring of forest growth conditions is the hyperspectral remote sensing. This technology gives an opportunity to economize human resources and time for data collecting and processing. The spectral behaviour of plant leaves depends on number of factors, including environmental background. The aim of this study was to assess the tree reflectance spectra in relation to the growth conditions to take into account potential differences for increasing precision of species identification in Latvian forests and for estimating of forest growth conditions. Remote sensing data were obtained using a specialized aircraft (Pilatus PC-6), which is equipped with a high-performance airborne VNIR pushbroom hyperspectral system (AisaEAGLE). The study area was flown at $1000 \mathrm{~m}$ altitude. Data was recorded in the 400-970 nm spectral range, spectral resolution was $3.3 \mathrm{~nm}$, ground resolution $0.5 \mathrm{~m}$. Data processing consisted of manually selecting trees with a recognizable tree crowns in the airborne images. Tree centres were adjusted by putting them in the accurate position according to the situation in aerial photography. All trees with a diameter at breast height DBH of more than $5 \mathrm{~cm}$ were measured and for each tree coordinates, its species, height, DBH, crown width and length were recorded. Differentially corrected Global Positioning System measurements were used to determine the position of each plot centre. Data from different hyperspectral bands were compared using ANOVA at confidence level $95 \%$. Four species: Scots pine (Pinus sylvestris L.), Norway spruce (Picea abies (L.) H. Karst), silver birch (Betula pendula Roth), and European aspen (Populus tremula L.) - were examined in distinct forest site types. The spectral response of studied species was 1) different between species and 2) different between site types within each species, correlating with soil fertility gradient and soil moisture gradient. Differences between species occurred most in the intensity of reflected electromagnetic radiation rather than distinctive locations of maximums or minimums in spectrum curve, and near infrared (NIR) region of spectrum showed more differences between species than visible light zone. Most informative wavebands for distinguishing differences between site types were $805 \mathrm{~nm}$ and $644 \mathrm{~nm}$.

Keywords: Hyperspectral, remote sensing, leaf reflectance, species identification, forest growth conditions, soil fertility, forest site types, forest mapping

\section{INTRODUCTION}

Efficient and sustainable management of forests requires modern inventory and monitoring methods. To save human resources, as well information acquisition and processing time, there is increasingly common used the hyperspectral remote sensing method. It may be used for mapping of vegetation, observing forest resources, monitoring forest health, identifying important food sources for wildlife etc.

The precept for species discrimination is that variability of spectral reflectance between different species exceeds variability within each species. They can be identified due to inherent similarities in leaf anatomy and biochemistry, which result in similarities in leaf spectral reflectance (Hoffer and Johannsen, 1969).

In ideal conditions, several tree species can be identified by hyperspectral imagery with a precision up to 97-98 \% (Dinuls et al., 2011; Dinuls et al., 2012). However, in practice there are several factors affecting the reflection from tree canopies. A complicating factor in classification of plant species is the dynamic nature of plant spectral signatures. Natural cycles such as

Copyright (C) 2015 The Authors. Published by Aleksandras Stulginskis University. This is an open-access article distributed under the terms of the Creative Commons Attribution License (CC-BY 4.0), which permits unrestricted use, distribution, and reproduction in any medium, provided the original author and source are credited. 
leaf flush and senescence, as well as health, light availability, and water supply, may contribute to changes in a species' spectral signature over time or at a given position in the canopy (Gausman, 1984; Carter, 1993; Noble and Brown, 2009).

The reflection peculiarities of tree canopies depend also on leaf water content, plant biomass, leaf area index (Adam et. al., 2010), and leaf bicolouration (Slaton et al., 2001). Likewise the accuracy of species identification can be affected by species-specific tree crown width, which determines whether the tree crown overlap with adjacent crowns of other species closer or further of tree centre. As well tree reflectance could be affected by plant leaf age, and stress status (Mohammed et al., 2000). Nutritional status of tree also can influence its spectral reflectance by inducing changes in biochemical composition and physiology of plants (Guangyu et al., 2012; Carter and Knapp, 2001; Gausman, 1984).

Leaf anatomical traits are suggested as essential factor for differentiating species by reflected spectra (Sims and Gamon, 2002). The spectral behaviour of plants, in particular, of leaves depends on their morphological, structural and chemical properties, and the capacity to distinguish species remotely may be more successful, taking into account speciesspecific tree architectural traits (Mohammed et al., 2000; Noble and Brown, 2009; Dinuls et al., 2012).

The surface of the leaf blade is covered by thinner or thicker semitransparent wax layer called cuticle. Underneath - the outer layer of leaf cells - the epidermis, which may be covered with hairs. Deeper, palisade cell layers are, with pigment containing chloroplasts (or another type of plastids). Below there is the spongy mesophyll with irregular shaped cells and large intercellular air spaces. The lower epidermis completes the leaf structure; this layer also contains the apertures of the stomata (Campbell, 1996; Schlesinger, 1997; Braune et al., 2009; Gibson, 2000). Any changes in these structures, caused by plant inheritance, leaf age or growth conditions, may affect absorption, transmittance and reflectance of electromagnetic waves (Fig. 1).

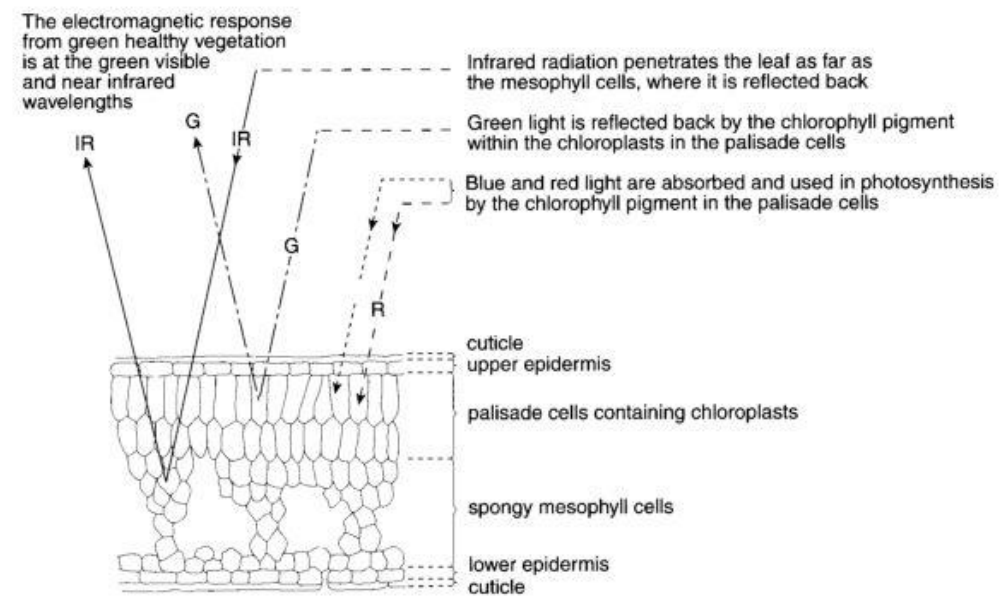

Figure 1. Cell structure of leaf blade and interactions with the electromagnetic radiation (Gibson, 2000)

Reflected electromagnetic radiation in the visible light region of spectrum (about 400-700 nm) depends on different pigment proportions and amounts in the leaf palisade cells, while the reflectance in near infrared (NIR) region (about 700 $\mathrm{nm}$ to $1250 \mathrm{~nm}$ ) bases on cell and tissue (especially mesophyll) structure distinctive features (Hoffer and Johannsen, 1969; Gibson, 2000). In SWIR (spectral region at 1250-3000 nm), there is particular response of leaf water content and biochemicals (Figure 2).

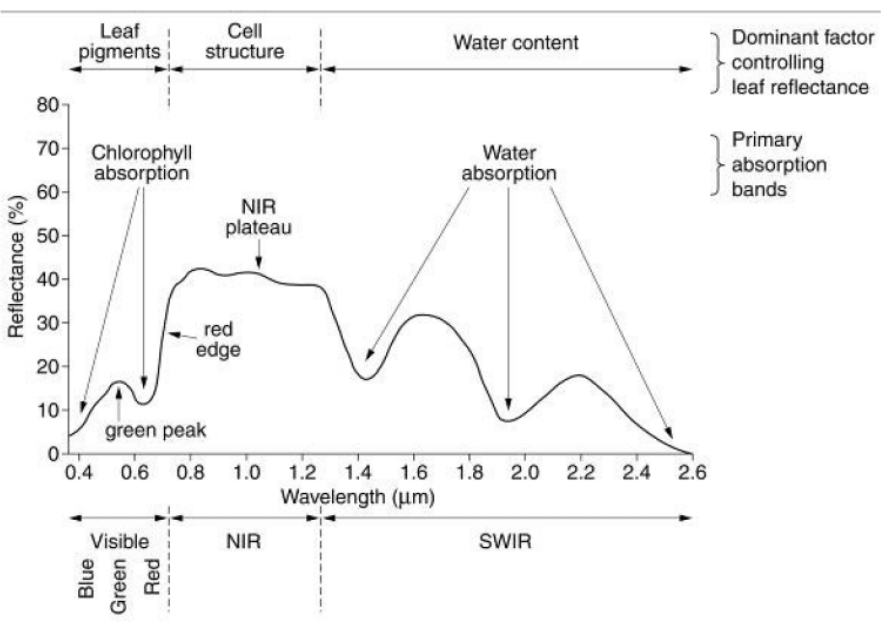

Figure 2. Plant leaf optical behaviour according to structural and biochemical traits (RIT Center for Imaging Science) 
The amount and proportions of pigments depends on plant species, as well on plenty of ecological factors: mineral nutrition facts, light and temperature, also on season (Mohammed et al., 2000).

The optimal wavebands for species identification vary during the growing season, and each species have unique seasonal time to be distinguished more precisely (Masaitis, 2013; Masaitis and Mozgeris, 2013). Mature leaves reflect more intensive than immature ones (Mohammed et al., 2000). Some scientists found out that species classification within a single site and season was successful, while classification between sites or seasons was not (Castro-Esau et al., 2006). More stable pigment content and representative species-specific anatomical traits of mature leaves are available at July and August (Burkholder, 2010; Slaton et al., 2001).

The red edge (ascending part of spectrum curve at 680-750 $\mathrm{nm}$ region) shifts itself for a single species as the plant grows and matures (Gibson, 2000). As well it can show some water stress and plant nutritional status evidence (Filella and Penuelas, 1994).

Specific increases and decreases of reflection in visible light zone and most at the red edge depend on kind of stress factor. This can be explained by the general tendency of stress to change leaf chlorophyll concentration (Carter and Knapp, 2001; Mohammed et al., 2000). Basing on this evidence, the red edge zone is useful for forest health monitoring (Masaitis et al., 2013). Many studies suggested that plants under stress have a decrease in reflectance of the NIR (near infrared, 700-1500 nm) bands, a reduced red absorption in the chlorophyll active band and a consequent shift of the red edge (Carter, 1993; Dobrowski et al., 2005). For plant health studies using chlorophyll content there are some highly sensitive wavebands: 540 to $630 \mathrm{~nm}$ and around $700 \mathrm{~nm}$ (Gitelson and Merzlyak, 1997).

Monitoring or examining plants in natural environment there must be kept in mind that plant is complicated and dynamic system and may have no immediate response to range of changing factors as it can be observed in laboratory. Analyzing the curve of reflected spectrum in coherence with current plant ecology and physiology, there is need to assume that pigment absorption bands give information more about current condition of plant, but long-lasting processes, with or without conjunction to pigments, sequentially lead to changes in leaf biochemical and leaf optical response in the NIR and SWIR.

Differentiated forest monitoring and forehanded detecting any shift in forest health is particularly important, so as climate changes and environment pollution may alter foliar quality and improve herbivore performance, furthermore distinct species response to environmental changes may shift differently from others (Couture et al., 2012). Shifts in plant appearance may occur because of climate changes alters soil quality, too (Várallyay, 2010).

The reflectance in the NIR region is considered to be more efficient than in the visible range, for example, distinguishing changes in plant growth conditions or plant health. If similar graphs are produced for diverse vegetation types, they are often quite similar in the visible range, but may markedly differ in the NIR. In case of water or nutrient stress, or a parasite infestation, the changes in the NIR region occur much earlier than in the visible range (and visually noticeable in practice), so that immediate remedial actions could take place (Mohammed et al., 2000; Gibson, 2000).

The intensity of reflected radiation in NIR region rely on leaf thickness and disposition, since part of NIR radiation transmit through 2-8 leaf layers and then is available for reflection. A dense crown or dense forest stand gives more intensive reflection as sparse ones (Gibson, 2000; Korpela et al., 2006). Forest canopy spectra may be changed under some drought status, as the lack of water would influence the canopy foliage mass (Lee et al., 2007).

Water content in plant leaves can be assessed using reflectance in water absorption spectrum bands in short wavelength infrared region (Jones et al., 2004). Although not only direct water content in leaves gives evidence about water regime in the site plant grows in. In the NIR region, there could be obtained several spectral changes caused by plant adaptation mechanisms to dryer growth conditions. These mechanisms include xeromorphic changes as thicker cuticle formation on the leaf surface, thicker leaf blades, epidermis and cell walls; potential loss of water has been inhibited by increasing protective hair density on the leaf surface (Walter and Breckle, 2013; Toole and Toole, 1999; Braune et al., 2009; Pyakurel and Wang, 2014). Such changes alter absorption, transmittance and reflection of electromagnetic waves. Such xeromorphic traits appear at the tops of taller trees (He et al., 2008) or in polluted environment, too (Christodoulakis and Fasseas, 1990).

Decrease of reflection intensity in pigment absorption region could be observed at unhealthy or shaded plants, as they have larger amount of chlorophylls to compensate influence of the stress factors. Sun leaves may be tougher than shade leaves and contains more lignin (Taylor and Parkinson, 1988). Some shaded plant leaf cells have thinner cell walls (Paul and Patterson, 1980). In addition, palisade mesophyll tissue of shaded plants have larger spaces between cells (Braune et al., 2009) so that the intensity of reflectance at NIR would be lower, since waves distribute in intercellular space (Gibson, 2000). In autumn, sun leaves in many species turn colour and fall before shade leaves (Gosz et al., 1972), so that airborne hyperspectral information may alter considerably during senescence period.

In the pigment absorption region, there could be reflectance differences associated with the physical and chemical characteristics of soil, as they influence plant biochemistry which appears in pigment content, too (Guangyu et al., 2012). In quantitative trait-based studies on a global scale, between-site variations of leaf traits were well explained by soil fertility if combined with climate factors (Ordonez et al., 2009).

To some extent, all soils have a certain inherent fertility. Acidic, alkaline, deficient in particular elements or waterlogged soils can support specific plant communities and can be regarded as fertile in relation to those communities. Therefore the soil fertility should be examined in the context with specific plant species or communities as each species has evolved to adapt to certain environments and therefore has contrasting requirements for nutrients (Ellis and Foth, 1997; Ordonez et al., 2009). Although, several forest site types are related to most soil groups, depending on the parent material, location and moisture conditions (Kasparinskis and Nikodemus, 2012). 
The aim of this study was to assess the tree reflectance spectra in relation to the growth conditions to take into account potential differences for increasing accuracy of species identification in Latvian forests and for estimating forest growth conditions.

\section{MATERIALS AND METHODS}

The study sites were selected with the aim to represent the regional variability in range of forest types according to different water regime and soil fertility. The studied forest was located in Latvia, at Jelgava district $\left(56^{\circ} 39^{\prime} \mathrm{N}, 2^{\circ} 47^{\prime}\right.$ E). The area consisted of mixed coniferous and deciduous forest with different age, high density, complex structure, and various composition and soil conditions.

Remote sensing data were obtained using a specialized aircraft (Pilatus PC-6), which is equipped with a highperformance airborne VNIR pushbroom hyperspectral system (AisaEAGLE). The study area was flown at $1000 \mathrm{~m}$ altitude. System acquires full, high quality hyperspectral data up to 488 spectral channels with 1024 swath pixels and high image rates. Data was recorded in 64 hyperspectral bands in the 400-970 nm spectral range, spectral resolution was 3.3 $\mathrm{nm}$, ground resolution $0.5 \mathrm{~m}$, a field of view from $17.36^{\circ}$ to $-18.68^{\circ}$. Flights were done on October 2014 .

In this study, four tree species were examined: Scots pine (Pinus sylvestris L.), Norway spruce (Picea abies (L.) H. Karst), silver birch (Betula pendula Roth), and European aspen (Populus tremula L.). In total 70 sample plots (0.05 ha each) were established. Study includes sample plot measurements for 915 trees: Scots pine (256 trees), Norway spruce (149 trees), silver birch (257 trees), and European aspen (253 trees). All trees with a diameter at breast height DBH of more than $5 \mathrm{~cm}$ were measured and for each tree coordinates, its species, height, DBH, crown width and length were recorded. Differentially corrected Global Positioning System measurements were used to determine the position of each plot centre. The precision of the positioning was less than 1 meter. It was performed with an aim to exclude miscalculations that could appear when inaccurate tree centres would be determined by using automated approach.

Individual trees from the sample plots were used in the study. Data processing consisted of manually selecting trees with a recognizable tree crowns in the images. Tree centres were adjusted by putting them in the accurate position according to the situation in aerial photography.

To find out differences between reflected spectra of different tree species in similar growth conditions, data of 64 hyperspectral bands were compared using ANOVA at confidence level $95 \%$. Before all calculations, the outliers were excluded from the data set. Graphs were made using means of the reflected energy values in each waveband, dividing by 1000 and denoting as notional units for easier comparison.

To find out relationships between the tree reflected spectra and tree growth conditions, the reflection values at 461 , 644, and $805 \mathrm{~nm}$ wavebands for samples from distinct species and site types were compared using ANOVA at confidence level $95 \%$. The rest of the 64 wavebands were used to construct the graphs for provisional depiction of mentioned relationships.

To make some opinion of meteorological background of studied forest site types in the corresponding growing season (and for comparison with another year in future), there was made a summary of daily rainfall and average air temperature according to data from Latvian Environment, Geology and Meteorology Centre (Figure 3).

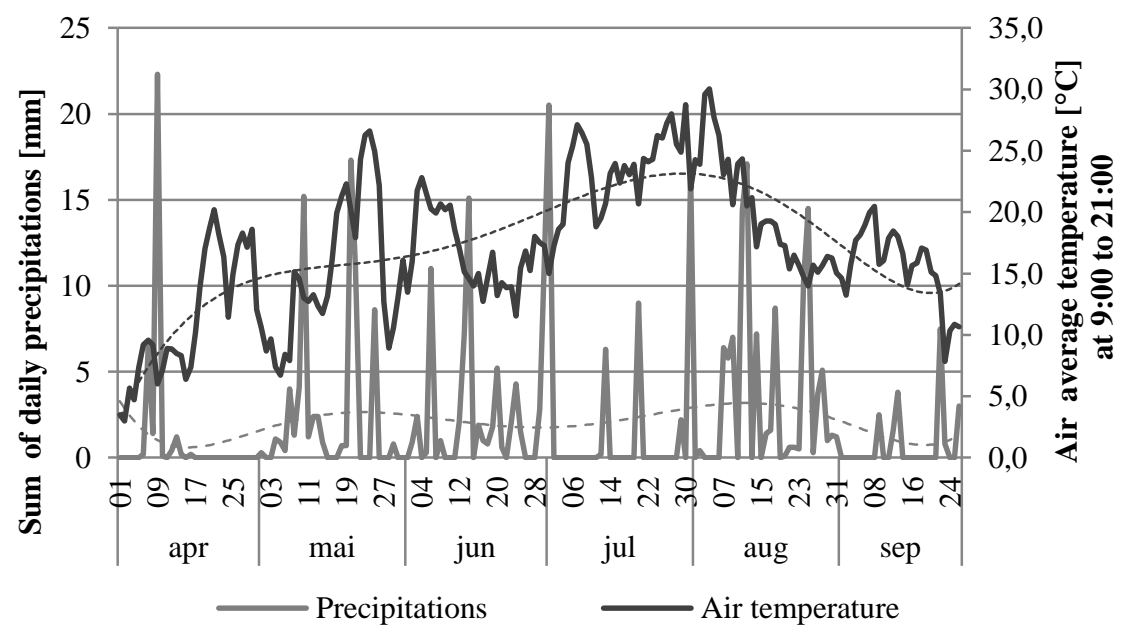

Figure 3. Meteorological background of studied forest site types in the corresponding growing season

The research was performed in twelve forest site types (Table 1).

The forest types and soil fertility gradient were defined according to the actual Latvian forest typology in context with the productivity of forest tree species. The soil fertility was estimated indirectly considering plant communities. Assessment in points for soil fertility and soil moisture was made to evaluate relationships between the forest growth conditions and the values of reflected radiation from tree canopies, mathematically. Correlations between plant reflection at $805 \mathrm{~nm}$ and soil fertility / moisture gradients were estimated using Pearson's correlation analysis. 
Table 1. Short characteristics of soil fertility and soil moisture in the studied forest types

\begin{tabular}{|c|c|c|c|c|c|}
\hline $\begin{array}{c}\text { Forest site } \\
\text { type }\end{array}$ & Soil characteristics & $\begin{array}{c}\text { Soil } \\
\text { fertility } \\
\text { in points }\end{array}$ & $\begin{array}{c}\text { Soil } \\
\text { moisture } \\
\text { in points } \\
\end{array}$ & Site-specific tree species & Undergrowth \\
\hline $\begin{array}{l}\text { Vacciniosa } \\
\text { mel. }^{3}\end{array}$ & $\begin{array}{l}\text { relatively poor, podsolic, } \\
\text { gleyic, sandy mineral soil; } \\
\text { groundwater level } \\
\text { approximately optimal }\end{array}$ & 2 & 3 & $\begin{array}{l}\text { Pinus sylvestris (II) }{ }^{4}, \\
\text { Betula pendula, rarely } \\
\text { Picea abies }\end{array}$ & $\begin{array}{l}\text { sparse; Juniperus } \\
\text { communis, Frangula } \\
\text { alnus }\end{array}$ \\
\hline $\begin{array}{c}\text { Mercurialosa } \\
\text { mel. }\end{array}$ & $\begin{array}{l}\text { rich, carbonate, slightly acidic } \\
\text { or neutral, gleyic, loam or clay } \\
\text { mineral soil; groundwater level } \\
\text { approximately optimal }\end{array}$ & 4 & 3 & $\begin{array}{l}\text { Picea abies (I-II), Betula } \\
\text { pendula, Alnus glutinosa, } \\
\text { Alnus incana, Fraxinus } \\
\text { excelsior, Populus } \\
\text { tremula } \\
\end{array}$ & $\begin{array}{l}\text { depressed; Frangula } \\
\text { alnus, Sorbus } \\
\text { aucuparia }\end{array}$ \\
\hline $\begin{array}{l}\text { Myrtillosa } \\
\quad \text { mel. }\end{array}$ & $\begin{array}{l}\text { medium rich, podsolic, acidic, } \\
\text { gleyic, loamy sand or loam } \\
\text { mineral soil; groundwater level } \\
\text { approximately optimal }\end{array}$ & 3 & 3 & $\begin{array}{l}\text { Pinus silvestris (I), Picea } \\
\text { abies, Betula pendula, } \\
\text { Populus tremula }\end{array}$ & $\begin{array}{l}\text { Sorbus aucuparia, } \\
\text { Frangula alnus, } \\
\text { Viburnum opulus, } \\
\text { Lonicera caerulea }\end{array}$ \\
\hline Hylocomiosa & $\begin{array}{l}\text { quite rich, podsolic, loamy sand } \\
\text { or loam, rarely clay mineral } \\
\text { soil; groundwater does not } \\
\text { directly affect roots of trees }\end{array}$ & 4 & 2 & $\begin{array}{l}\text { Pinus silvestris (I), Picea } \\
\text { abies, Betula pendula, } \\
\text { Populus tremula }\end{array}$ & $\begin{array}{l}\text { medium density; Sorbus } \\
\text { aucuparia, Corylus } \\
\text { avellana, Frangula } \\
\text { alnus }\end{array}$ \\
\hline Vacciniosa & $\begin{array}{l}\text { poor, podsolic, sandy mineral } \\
\text { soil; groundwater does not } \\
\text { directly affect roots of trees }\end{array}$ & 2 & 2 & $\begin{array}{l}\text { Pinus silvestris (III), } \\
\text { Betula pendula, Picea } \\
\text { abies }\end{array}$ & $\begin{array}{l}\text { sparse or absent; } \\
\text { Juniperus communis, } \\
\text { Sorbus aucuparia }\end{array}$ \\
\hline Oxalidosa & $\begin{array}{l}\text { rich, with rapid nutrient } \\
\text { cycling, podsolic, loamy sand, } \\
\text { loam or clay mineral soil; } \\
\text { groundwater does not directly } \\
\text { affect roots of trees }\end{array}$ & 4 & 2 & $\begin{array}{l}\text { Picea abies (I), Betula } \\
\text { pendula, Populus } \\
\text { tremula, Alnus spp. }\end{array}$ & $\begin{array}{l}\text { In Picea abies grove: } \\
\text { depressed, other tree } \\
\text { grove: medium density; } \\
\text { Sorbus aucuparia, } \\
\text { Corylus avellana } \\
\end{array}$ \\
\hline $\begin{array}{l}\text { Myrtilloso- } \\
\text { sphagnosa }\end{array}$ & $\begin{array}{l}\text { medium rich, strongly podsolic, } \\
\text { gleyic, sandy mineral soil with } \\
\text { layers of clay or loamy sand; } \\
\text { groundwater level uneven }\end{array}$ & 3 & 3 & $\begin{array}{l}\text { Pinus silvestris (III), } \\
\text { Betula pendula, Picea } \\
\text { abies (IV) }\end{array}$ & $\begin{array}{l}\text { sparse or medium } \\
\text { density: Frangula } \\
\text { alnus, Juniperus } \\
\text { communis, Salix } \\
\text { cinerea }\end{array}$ \\
\hline Dryopteriosa & $\begin{array}{l}\text { rich, carbonate, gleyic, loamy } \\
\text { sand, loam or clay mineral soil; } \\
\text { groundwater level uneven }\end{array}$ & 5 & 4 & $\begin{array}{l}\text { Picea abies (I-III), } \\
\text { Fraxinus excelsior, Alnus } \\
\text { glutinosa, Betula } \\
\text { pendula, Quercus robur }\end{array}$ & $\begin{array}{l}\text { medium density or } \\
\text { dense; Frangula alnus, } \\
\text { Padus avium, Ribes } \\
\text { nigrum, Frangula alnus }\end{array}$ \\
\hline $\begin{array}{l}\text { Dryopterioso- } \\
\text { caricosa }\end{array}$ & $\begin{array}{l}\text { rich, acidic, peaty; groundwater } \\
\text { level high }\end{array}$ & 4 & 5 & $\begin{array}{l}\text { Betula pendula, Alnus } \\
\text { glutinosa (III-IV), Picea } \\
\text { abies }\end{array}$ & $\begin{array}{l}\text { medium density; } \\
\text { Frangula alnus, Salix } \\
\text { spp., Padus avium }\end{array}$ \\
\hline $\begin{array}{l}\text { Vacciniosa } \\
\text { turf. mel. }\end{array}$ & $\begin{array}{l}\text { poor, acidic, low decomposed } \\
\text { peat; groundwater level } \\
\text { approximately optimal }\end{array}$ & 2 & 3 & $\begin{array}{l}\text { Pinus silvestris (II), } \\
\text { Betula pendula, Picea } \\
\text { abies }\end{array}$ & $\begin{array}{l}\text { sparse; Frangula alnus, } \\
\text { Juniperus communis, } \\
\text { Salix spp., Betula } \\
\text { humilis }\end{array}$ \\
\hline $\begin{array}{l}\text { Oxalidosa } \\
\text { turf. mel. }\end{array}$ & $\begin{array}{l}\text { rich, slightly acidic, strong } \\
\text { decomposed peat; groundwater } \\
\text { level approximately optimal }\end{array}$ & 4 & 3 & $\begin{array}{l}\text { Picea abies (I), Betula } \\
\text { pendula, Alnus glutinosa, } \\
\text { Pinus silvestris, Fraxinus } \\
\text { excelsior, Populus } \\
\text { tremula }\end{array}$ & $\begin{array}{l}\text { medium depressed; } \\
\text { Frangula alnus, Sorbus } \\
\text { aucuparia, Ribes } \\
\text { nigrum, Viburnum } \\
\text { opulus } \\
\end{array}$ \\
\hline $\begin{array}{l}\text { Myrtillosa } \\
\text { turf. mel. }\end{array}$ & $\begin{array}{l}\text { medium rich, medium acidic, } \\
\text { strong decomposed peat; } \\
\text { groundwater level } \\
\text { approximately optimal }\end{array}$ & 3 & 3 & $\begin{array}{l}\text { Pinus silvestris (I), Picea } \\
\text { abies (I), Betula pendula }\end{array}$ & $\begin{array}{l}\text { medium depressed; } \\
\text { Frangula alnus, Sorbus } \\
\text { aucuparia, Juniperus } \\
\text { communis }\end{array}$ \\
\hline
\end{tabular}

${ }^{1}$ Soil fertility: 1 - very low (not showed in this research), 2 - low, 3 - medium, 4 - over medium, 5 - high

${ }^{2}$ Soil moisture: 1 - dry (not showed in this research); 2 - mesophytic; 3 - medium; 4 - wet; 5 - damp

${ }^{3}$ mel. - meliorated mineral soils, turf. mel. - meliorated peat soils

${ }^{4}$ quality of locality: from I (the highest) to V (the lowest)

\section{RESULTS AND DISCUSSION}

The first results of our research show some specific traits in the plant reflection behaviour of each studied species as well some differences in that behaviour between trees from distinct forest site types.

We noticed much higher reflection energy for European aspen in all forest site types. Possibly, the reason of this evidence is in morphology of aspen leaves. They are bicolourated: green above, paler underneath, and have flattened stalk 
that is longer than the leaf, so that the leaf blade easily turns itself upside-down, trembling even in weak breeze. Other scientists have made similar observations for bicolourated leaves (Slaton et al., 2001). Another deciduous species have much less opportunities to turn their leaves upside-down, while the conifers almost have no such opportunity. Furthermore conifers have different leaf structure other than deciduous. They have thicker cuticle on needles, their mesophyll tissue contains cells with folded cell wall, but epidermis have heavily thickened cell walls (Braune et al., 2009) so that NIR reflection should be lower than of deciduous (Mohammed et al., 2000; Gibson, 2000). Our research confirmed the same tendencies that conifers reflect less than deciduous in the NIR (Figure 4).

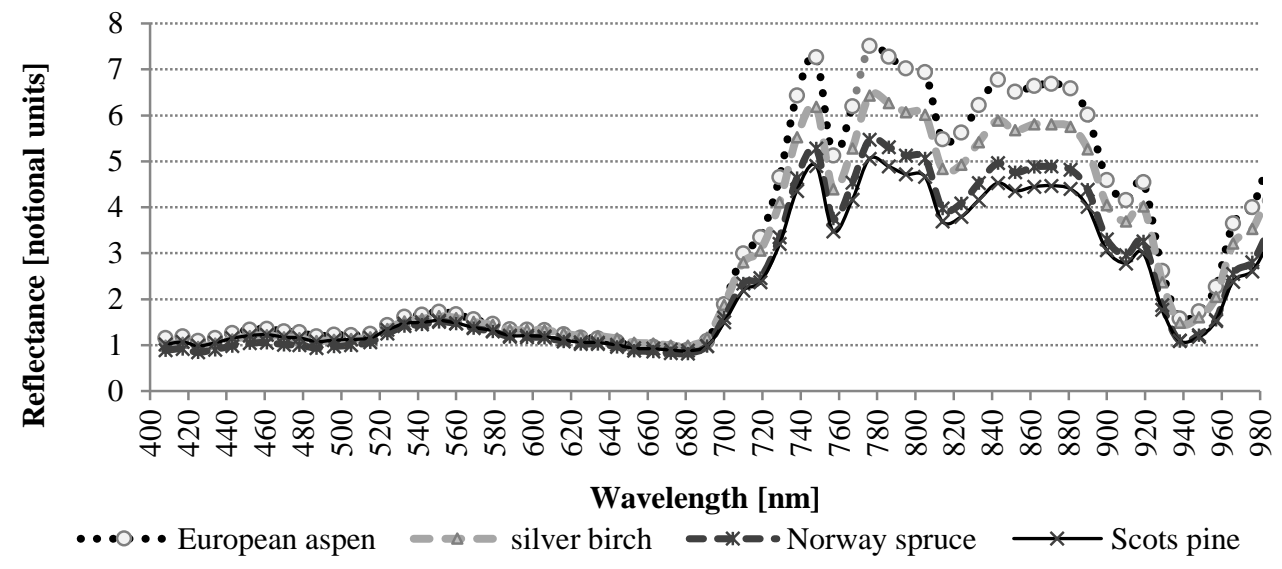

Figure 4. Different reflection between distinct species; forest site type: Hylocomiosa

In our case, the NIR region appeared more informative for distinguishing species than the spectral zone of visible light where reflection intensity of species was quite similar. Using ANOVA analysis at confidence level $95 \%$, differences between species in 843-955 $\mathrm{nm}$ zones appeared to be significant, but in 408-833 $\mathrm{nm}$ zones did not. This corresponds to observations of other researchers (Mohammed et al., 2000; Gibson, 2000). Differences between species in similar growth conditions occurred most in the intensity of reflected electromagnetic radiation rather than distinctive locations of maximums or minimums in spectrum curve.

Results of this research show differences of reflected information from tree canopies within species, depending on the forest site type (Fig. 5).

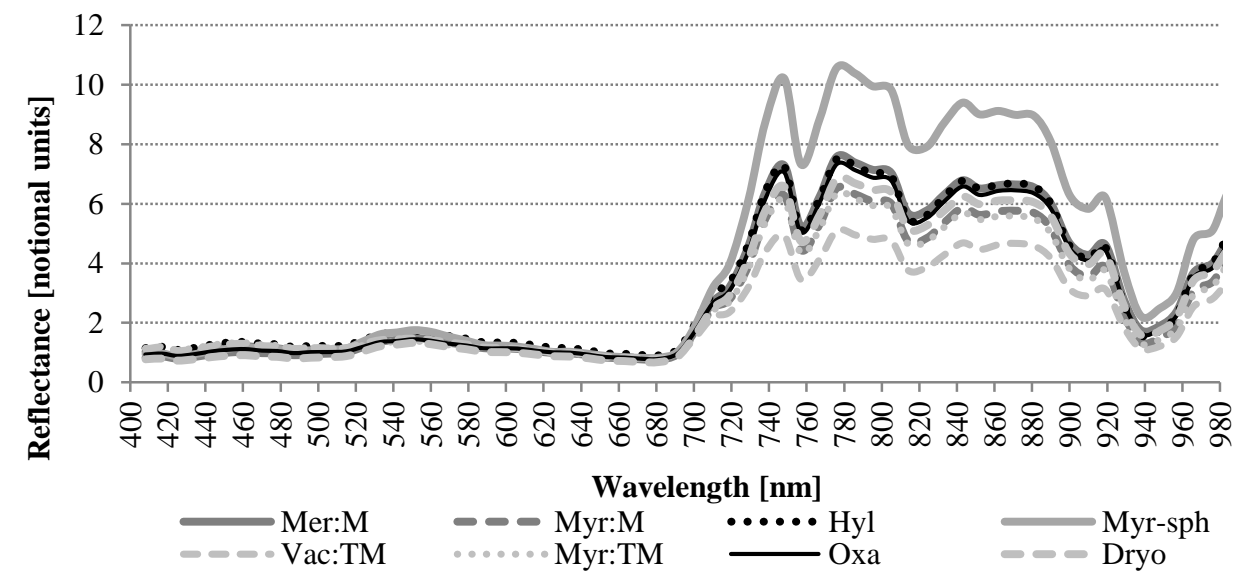

Figure 5. Reflection in different spectral bands from European aspen canopies of distinct forest site types; Forest site types: Mer:M - Mercurialosa mel., Myr:M - Myrtillosa mel., Hyl - Hylocomiosa, Myr-sph - Myrtilloso-sphagnosa, Vac:TM - Vacciniosa turf. mel., Myr:TM - Myrtillosa turf. mel., Oxa - Oxalidosa, Dryo - Dryopteriosa

Comparing the reflection of each species at different site types, the reflection values were examined at the 461, 644 and $805 \mathrm{~nm}$ bands. Using ANOVA at $95 \%$ confidence level, significant differences were found at 644 and $805 \mathrm{~nm}$ bands, but at $461 \mathrm{~nm}$ were not. Probably, that is for the fact, that analysis of the pigment absorption bands can be obstructed by the evidence that there is a sum signal of several pigments at $461 \mathrm{~nm}$, not a single pigment signal as in laboratory (Wozniak et al., 1998). Another possible reason for such occurrence: at the study period, there was senescence and chlorophyll degradation started already, and the results in carotenoid absorption bands made larger data distribution as undergoing dynamic proportions between chlorophylls and carotenoids.

Within the same species, differences in reflection between sampling sites may occur according to species specific response to growth conditions. The European aspen leaves from wet and fertile site type Myrtilloso-sphagnosa reflected much more than from Vacciniosa turf. mel., where soil was dryer and less fertile (Fig. 5, Tab. 1). This coincides with the 
opinion that aspen prefers moist fertile soil. Higher reflection in NIR commonly is considered as evidence of suitable growth conditions and good health of plant (Gibson, 2000). In addition, in this growing season there was decrease of precipitations and increase of air temperature in July, followed by period with strongly increased precipitations in August (Fig. 3), so that in Vacciniosa turf. mel. site there could be water stress for plants - some drought in midsummer and water saturated after.

In most site types, for three of studied species - European aspen, silver birch and Norway spruce - the spectral response at $805 \mathrm{~nm}$ correlated significantly with the soil fertility gradient (respectively $\mathrm{r}=0.15$ for aspen, $\mathrm{r}=0.24$ for birch, $\mathrm{r}=0.34$ for spruce) while for Scots pine did not. Silver birch, Norway spruce and Scots pine showed negative correlation with soil moisture gradient ( $\mathrm{r}=-0.33$ for birch, $\mathrm{r}=-0.22$ for spruce, $\mathrm{r}=-0.13$ for pine), (Fig. 6). (Disposition of values of the reflection for each species in the graph follows the gradient line to some extent.)

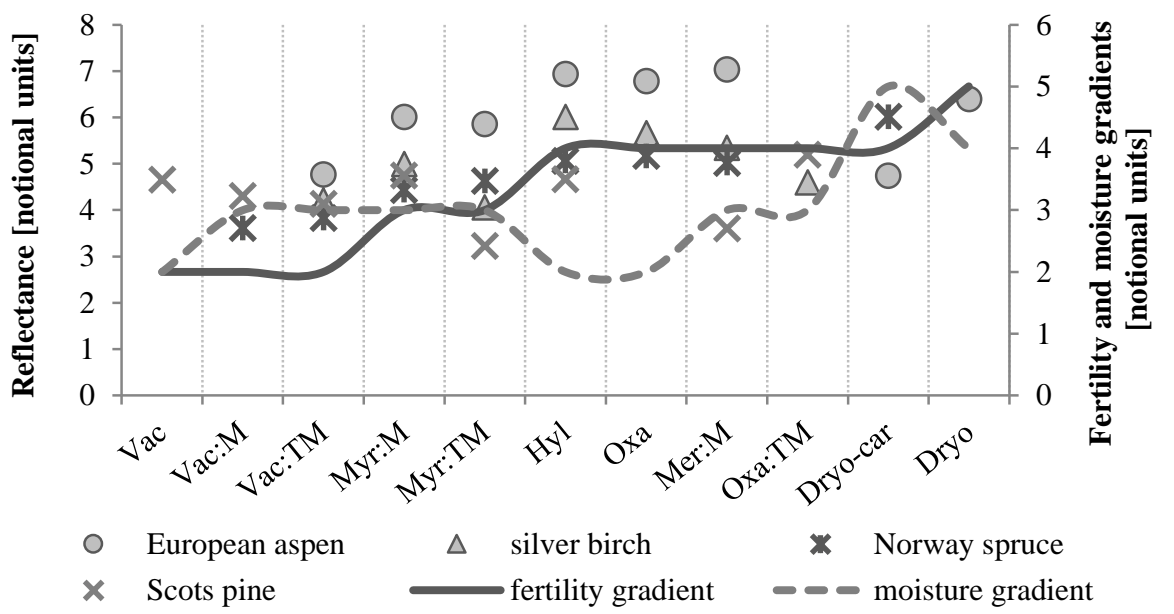

Figure 6. Reflection at $805 \mathrm{~nm}$ of studied species in correlation with the soil fertility and soil moisture gradients; Forest site types: Vac - Vacciniosa, Vac:M - Vacciniosa mel., Vac:TM - Vacciniosa turf. mel., Myr:M - Myrtillosa mel., Myr:TM - Myrtillosa turf. mel., Hyl - Hylocomiosa, Oxa - Oxalidosa, Mer:M - Mercurialosa mel., Oxa:TM - Oxalidosa turf. mel., Dryo-car - Dryopteriosa-caricosa, Dryo Dryopteriosa

The observations of this study should be subjected for further processing to compare with corresponding data of studied trees diameter, height, age, and crown width to evaluate relationships between reflectance of canopies and real appearance of trees. The gradients of soil fertility and soil moisture (in points) could be defined more detailed or even more composed together considering interactions between these two factors in context with the physiological abilities and ecological requirements of each species.

\section{CONCLUSIONS}

Canopies of different tree species had quite similar reflection results in the visible region of spectrum, most differences were observed in near infrared region.

Differences between species occurred most in the height of reflection curve rather than distinctive locations of maximums or minimums.

Within each studied species, the $805 \mathrm{~nm}$ and $644 \mathrm{~nm}$ wavebands were more informative than $461 \mathrm{~nm}$ waveband distinguishing differences between site types, during senescence period.

In most site types, spectral response of European aspen, silver birch and Norway spruce at $805 \mathrm{~nm}$ correlated with the soil fertility gradient, and the Scots pine had negative correlation with soil moisture gradient in turf. mel. site types.

Acknowledgement.This research was part of the project "Technology for remote forest inventory using hyper spectral and LiDAR data" (State Education Development Agency, Latvia University of Agriculture, contract number:

2014/0050/2DP/2.1.1.1.0/14/APIA/VIAA/048), funded by the European Regional Development Fund.

\section{REFERENCES}

1. Adam, E., Mutanga, O., Rugege, D., 2010. Multispectral and hyperspectral remote sensing for identification and mapping of wetland vegetation: a review. Wetlands Ecology and Management, Vol. 18, Iss. 3, pp. 281-296. http://dx.doi.org/10.1007/s11273$\underline{009-9169-\mathrm{z}}$

2. Braune, W., Leman, A, Taubert, H. 2009. Pflanzenanatomisches Praktikum I. Springer-Verlag, p. 175.

3. Burkholder, A. 2010. Seasonal trends in separability of leaf reflectance spectra for Ailanthus altissima and four other tree species. ProQuest Dissertations And Theses, 49(02), p. 38, Masters Abstracts International, West Virginia University.

4. Campbell, J. B. 1996. Introduction to Remote Sensing. Taylor \& Francis Ltd.

5. Carter, G. A. 1993. Responses of leaf spectral reflectance to plant stress. American Journal of Botany, Vol. 80, No. 3, pp. 239-243.http://dx.doi.org/10.2307/2445346 
6. Carter, G. A., Knapp, A. K. 2001. Leaf optical properties in higher plants: linking spectral characteristics to stress and chlorophyll concentration. American Journal of Botany, Vol. 88, No. 4, pp. 677-684. http://dx.doi.org/10.2307/2657068

7. Castro-Esau, K. L., Sanchez-Azofeifa, G. A., Quesada, M., Rivard, B., Wright, S. J. 2006. Variability in leaf optical properties of mesoamerican trees and the potential for species classification. American Journal of Botany, Vol. 93, No. 4, pp. 517-530. http://dx.doi.org/10.3732/ajb.93.4.517

8. Christodoulakis, N. S., Fasseas, C. 1990. Air pollution effects on the leaf structure of Laurus nobilis, an injury resistant species. Bulletin of Environmental Contamination and Toxicology, Vol. 44, Iss. 1, pp. 276-281. http://dx.doi.org/10.1007/BF01700147

9. Coates, K. D., Lilles, E. B., Astrup, R. 2013. Competitive interactions across a soil fertility gradient in a multispecies forest. Journal of Ecology, Vol. 101, Iss. 3, pp. 806-818. http://dx.doi.org/10.1111/1365-2745.12072

10. Couture, J. J., Meehan, T. D., Lindroth, R. L. 2012. Atmospheric change alters foliar quality of host trees and performance of two outbreak insect species. Oecologia, Vol. 168, Iss. 3, pp. 863-876. http://dx.doi.org/10.1007/s00442-011-2139-1

11. Dinuls, R., Erins, G., Lorencs, A., Mednieks, I., Sinica-Sinavskis, J. 2012. Tree species identification in mixed Baltic forest using LIDAR and multispectral data. Selected Topics in Applied Earth Observations and Remote Sensing, Vol. 5, Iss. 2, pp. $594-603$. http://dx.doi.org/10.1109/JSTARS.2012.2196978

12. Dinuls R., Lorencs A., Mednieks I. 2011. Performance Comparison of Methods for Tree Species Classification in Multispectral Images. Electronics and Electrical Engineering, No. 5, pp. 119-122. http://dx.doi.org/10.5755/j01.eee.111.5.371

13. Dobrowski, S. Z.; Pushnik, J.C.; Zarco-Tejada, P.J.; Ustin, S.L. 2005. Simple reflectance indices track heat and water stress-induced changes in steady-state chlorophyll fluorescence at the canopy scale. Remote sensing of environment, Vol. 97, Iss. 3, pp. $403-414$. http://dx.doi.org/10.1016/j.rse.2005.05.006

14. Ellis, B., Foth, H. 1997. Soil Fertility, 2nd ed., Technology \& Engineering, CRC Press, p. 304.

15. Filella, I., Penuelas, J. 1994. The red edge position and shape as indicators of plant chlorophyll content, biomass and hydric status. International Journal of Remote Sensing, Vol. 15, Iss. 7, pp. 1459-1470. http://dx.doi.org/10.1080/01431169408954177

16. Gausman, H. W., 1984. Evaluation of factors causing reflectance differences between sun and shade leaves. Remote Sensing of Environment, Vol. 15, Iss. 2, pp. 177-181. http://dx.doi.org/10.1016/0034-4257(84)90045-2

17. Gibson, P.J. 2000. Introductory Remote Sensing: Principles and Concepts. Routledge, London, pp. $26-28$.

18. Gitelson, A. A., Merzlyak, M. N. 1994. Spectral reflectance changes associated with autumn senescence of Aesculus hippocastanum L. and Acer platanoides L. leaves: spectral features and relation to chlorophyll estimation. Journal of Plant Physiology, Vol. 143, Iss. 3, pp. 286-292. http://dx.doi.org/10.1016/S0176-1617(11)81633-0

19. Gitelson, A.A., Merzlyak, M.N. 1997. Remote estimation of chlorophyll content in higher plant leaves. International Journal of Remote Sensing, Vol. 18, Iss. 12, pp. 2691-2697. http://dx.doi.org/10.1080/014311697217558

20. Gosz, J. R., Likens, G. E., Bormann, F. H. 1972. Nutrient Content of Litter Fall on the Hubbard Brook Experimental Forest. New Hampshire Ecology, Vol. 53, Iss. 5, pp. 769-784. http://dx.doi.org/10.2307/1934293

21. Guangyu, C., Taihui, Z., Jian, M., Yi, S., Xin, C. 2012. Changes in Spectral Reflectance of Vegetation in Response to Specific Nutrient Supply. Advances in Electric and Electronics, Vol. 155, pp. 671-675. http://dx.doi.org/10.1007/978-3-642-28744-2_87

22. He, C. X., Li, J. Y., Zhou, P., Guo, M., Zheng, Q. S. 2008. Changes of leaf morphological, anatomical structure and carbon isotope ratio with the height of the Wangtian tree Parashorea chinensis in Xishuangbanna, China. Journal of Integrative Plant Biology, Vol. 50, Iss. 2, pp. 168-173. http://dx.doi.org/10.1111/j.1744-7909.2007.00620.x

23. Hoffer, R. M., Johannsen, C. J. 1969. Ecological potentials in spectral signature analysis. In P. L. Johnson ed., Remote sensing in ecology, University of Georgia, Athens, Georgia, USA.

24. Jones, C. L., Weckler, P. R., Maness, N. O., Stone, M. L., Jayasekara R. 2004. Estimating Water Stress in Plants Using Hyperspectral Sensing. Presentation at the "2004 ASAE/CSAE Annual International Meeting", pp. 1-4, The Westin, Government Centre Ottawa, Ontario, Canada.

25. Kasparinskis, R., Nikodemus, O. 2012. Influence of environmental factors on the spatial distribution and diversity of forest soil in Latvia. Estonian Journal of Earth Sciences, Vol. 61. Iss. 1, pp. 48-64. http://dx.doi.org/10.3176/earth.2012.1.04

26. Korpela, I., 2006. Incorporation of Allometry into Single-tree Remote Sensing with LIDAR and Multiple Aerial Images. Department of Forest Resource Management. University of Helsinki, Finland, p. 6.

27. Lee, K. S., Kook, M. J., Shin, J. I., Kim, S. H., Kim, T. G. 2007. Spectral Characteristics of Forest Vegetation in Moderate Drought Condition Observed by Laboratory Measurements and Spaceborne Hyperspectral Data. Estonian Journal of Earth Sciences, Vol. 73, Iss. 10, pp. 1121-1127. http://dx.doi.org/10.14358/PERS.73.10.1121

28. Masaitis, G. 2013. The potential of hyperspectral imaging to detect forest tree species and evaluate their condition. Summary, Agricultural Sciences, Forestry, Akademija, Lithuania.

29. Masaitis, G., Mozgeris, G. 2013. The influence of the growing season on the spectral reflectance properties of forest tree species. Proceedings of the International Scientific Conference "Rural Development 2013", Vol. 2, pp. 20-25, Latvian University of Agriculture.

30. Masaitis, G., Mozgeris, G., Augustaitis, A. 2013. Spectral reflectance properties of healthy and stressed coniferous trees. iForestBiogeosciences and Forestry, Vol. 6, pp. 30-36.

31. Mohammed, G. H., Sampson, P. H., Miller, J. R., Noland, T. L., Zarco-Tejada, P. J., Irving, D. 2000. Natural and stress-induced effects on leaf spectral reflectance in Ontario. Forest Research Report, p. 156.

32. Noble, S. D., Brown, R. B. 2009. Plant species discrimination using spectral/spatial descriptive statistics. Proceedings of the $1 \mathrm{st}$ International Workshop on Computer Image Analysis in Agriculture, 27-28 August, pp. 82-92, Potsdam.

33. Ordonez, J. C., van Bodegom, P. M., Witte, J. P. M., Wright, I. J., Reich, P. B. 2009. A global study of relationships between leaf traits, climate and soil measures of nutrient fertility. Global Ecology and Biogeography, Vol. 18, Iss. 2, pp. 137-149. $\underline{\text { http://dx.doi.org/10.1111/j.1466-8238.2008.00441.x }}$ 
34. Paul, R. N., Patterson, D. T. 1980. Effects of Shading on the Anatomy and Ultrastructure of the Leaf Mesophyll and Vascular Bundles of Itchgrass Rottboellia exaltata. Weed Science, Vol. 28, Iss. 2, pp. 216-224.

35. Pyakurel, A., Wang, J. R. 2014. Leaf Morphological and Stomatal Variations in Paper Birch Populations along Environmental Gradients in Canada. American Journal of Plant Sciences, vol. 5, pp. 1508-1520. http://dx.doi.org/10.4236/ajps.2014.511166

36. RIT Center for Imaging Science, Environmental Applications of Remote Sensing, Vegetation reflectance spectrum. Available at http://www.cis.rit.edu/class/simg553_01/vegFig3.gif (accessed on 15/06/2015).

37. Schlesinger, W. H. 1997. Biogeochemistry, an analysis of global change. Academic Press, p. 588.

38. Sims, D. A., Gamon, J. A. 2002. Relationships between leaf pigment content and spectral reflectance across a wide range of species, leaf structures and developmental stages. Remote Sensing of Environment, vol. 81, Iss. 2-3, pp. 337-354. http://dx.doi.org/10.1016/S0034-4257(02)00010-X

39. Slaton, M. R., Hunt, R. E. Jr., Smith, W. K. 2001. Estimating near-infrared leaf reflectance from leaf structural characteristics. American Journal of Botany, Vol. 88, No. 2, pp. 278-84. http://dx.doi.org/10.2307/2657019

40. Taylor, B. R., Parkinson, D. 1988. Annual differences in quality of leaf litter of aspen Populus tremuloides affecting rates of decomposition. Canadian Journal of Botany, Vol. 66, No. 10, pp. 1940-1947.

41. Toole, G., Toole, S., Thornes, N. 1999. Understanding Biology for Advanced Level. Juvenile Nonfiction, p. 460.

42. Várallyay, G. 2010. The impact of climate change on soils and on their water management. Agronomy Research, Vol. 8, Special Issue II, pp. 385-396.

43. Walter, H., Breckle, S. 2013. Ecological Systems of the Geobiosphere: 1 Ecological Principles in Global Perspective. Technology \& Engineering, Jun 29, p. 142.

44. Wozniak, B., Dera, J., Ficek, D., Majchrowski, R., Kaczmarek, S., Ostrowska, M., Koblentz-Mishke, O. I. 1998. Algorithm for calculation of marine phytoplankton pigments Non-packaged spectral absorption coefficient. Modelling the influence of photoand chromatic acclimation on the absorption properties of marine phytoplankton. Proceedings of "Ocean Optics Conference", p. 10-13, Kailua-Kona, Hawaii, USA. 